\title{
Review \\ Contribution of Precision Livestock Farming Systems to the Improvement of Welfare Status and Productivity of Dairy Animals
}

\author{
Panagiotis Simitzis ${ }^{1, *(\mathbb{D})}$, Christos Tzanidakis ${ }^{2}$, Ouranios Tzamaloukas ${ }^{3}{ }^{(D)}$ and Evangelia Sossidou 4 \\ 1 Laboratory of Animal Breeding and Husbandry, Department of Animal Science, Agricultural University of \\ Athens, 75 Iera Odos, 11855 Athens, Greece \\ 2 Laboratory of Farm Structures, Department of Natural Resources Management and Agricultural Engineering, \\ Agricultural University of Athens, 75 Iera Odos, 11855 Athens, Greece; ctzan@aua.gr \\ 3 Department of Agricultural Sciences, Biotechnology and Food Science, Cyprus University of Technology, \\ Limassol 3036, Cyprus; ouranios.tzamaloukas@cut.ac.cy \\ 4 Veterinary Research Institute, Ellinikos Georgikos Organismos DIMITRA, 57001 Thessaloniki, Greece; \\ sossidou@vri.gr \\ * Correspondence: pansimitzis@aua.gr; Tel.: +30-2105-294-427
}

check for updates

Citation: Simitzis, P.; Tzanidakis, C.; Tzamaloukas, O.; Sossidou, E. Contribution of Precision Livestock Farming Systems to the Improvement of Welfare Status and Productivity of Dairy Animals. Dairy 2022, 3, 12-28. https://doi.org/10.3390/dairy 3010002

Academic Editors: Mariangela Caroprese and Burim Ametaj

Received: 7 September 2021

Accepted: 16 December 2021

Published: 29 December 2021

Publisher's Note: MDPI stays neutral with regard to jurisdictional claims in published maps and institutional affiliations.

Copyright: (c) 2021 by the authors. Licensee MDPI, Basel, Switzerland. This article is an open access article distributed under the terms and conditions of the Creative Commons Attribution (CC BY) license (https:/ / creativecommons.org/licenses/by/ $4.0 /)$.

\begin{abstract}
Although the effects of human-dairy cattle interaction have been extensively examined, data concerning small ruminants are scarce. The present review article aims at highlighting the effects of management practices on the productivity, physiology and behaviour of dairy animals. In general, aversive handling is associated with a milk yield reduction and welfare impairment. Precision livestock farming systems have therefore been applied and have rapidly changed the management process with the introduction of technological and computer innovations that contribute to the minimization of animal disturbances, the promotion of good practices and the maintenance of cattle's welfare status and milk production and farms' sustainability and competitiveness at high levels. However, although dairy farmers acknowledge the advantages deriving from the application of precision livestock farming advancements, a reluctance concerning their regular application to small ruminants is observed, due to economic and cultural constraints and poor technological infrastructures. As a result, targeted intervention training programmes are also necessary in order to improve the efficacy and efficiency of handling, especially of small ruminants.
\end{abstract}

Keywords: small ruminants; aversive handling; precision livestock farming systems; animal welfare; milk production

\section{Introduction}

The demand for dairy products is constantly increased as a result of the world population increment, which is expected to rise from 7.7 billion in 2019 to 9.7 billion by the year 2050 [1]. Over the previous decades, intensive farming systems have been extensively applied in order to cover consumers' needs and requirements. Although dairy farms around the world are growing in size due to the rising costs and additional benefits of economies of scale, the husbandry staff to animal ratio is decreasing [2]. On the other hand, milk yield and quality requirements are constantly rising (i.e., lower accepted somatic cell thresholds), resulting in higher energy demands per $\mathrm{kg}$ of milk and less time for the farmer to spend with individual animals [3-5]. This intensification is often related to group-oriented husbandry practices, due to limited capital and labour availability, which could lead to the poor management and impairment of animals' well-being, resulting in a diminished productivity and competence of units [6]. Although, the herd size cannot be considered a feasible indicator of the on-farm animal welfare level [7], other parameters that could be affected by the herd size such as the health status and water accessibility could negatively affect the welfare status [8]. Approximately $20 \%$ of the milk yield is lost 
due to improper management, and appropriate practices are necessary for the attainment of high productivity and welfare levels [9]. As it can be concluded, an improved welfare status and appropriate management practices are strongly related with the efficiency and efficacy of dairy systems [10]. However, it is important to point out that increased productivity is not necessarily associated with high levels of welfare. An improved health status, a normal growth performance and reproductive function, and high milk yield levels could be considered sound indicators of improved animal welfare; however, there are also other parameters that probably integrate both the health status and productivity of farm animals, such as their longevity and display of natural behaviours [11].

Although a high productivity is generally associated with an increased yield and improved quality of the derived milk, dairy animal welfare is a complex concept that combines the mental and physical aspects of the animal and is not similarly defined and perceived around the world [12]. Welfare can be defined as the state of harmony between an individual and its environment, and it is based on the adequacy of the individual to cope with its environment [13]. Any observed divergence from this equilibrium, if perceived by the individual, causes a welfare deficit due to negative emotional experiences [14]. Most of the examined quantifiable welfare indicators currently refer to negative aspects—such as high levels of stress hormones (i.e., corticosteroids, cortisol and prostaglandins); abnormal behaviours (i.e., stereotypes, tongue rolling, cross-sucking, urine licking and wool eating); aggressiveness; fear (i.e., ears pinned back or wide-eyed animals); diseases and lameness-since a deficit of knowledge exists regarding the valid interpretation of the mental state of animals [15]. However, it is generally accepted that welfare is fulfilled when animals experience positive emotions and do not remain in a negative emotional status for a prolonged period [14]. This recognition has recently contributed to the consideration of the concepts of 'animal happiness' and 'a life worth living', where the emphasis has shifted from negative to positive aspects of animal welfare [16]. Fraser [17] categorized the main scientific approaches that are used for the definition of animal welfare into three groups, based either on: the physiological functions of the animals (objective); the emotions and mood experienced by them (subjective), ranging from depression to pleasure; or the similarity of the rearing conditions to their natural state (natural living/naturalness). Dairy animals should be provided with a range of stimuli that offer freedom (the 'Five Freedoms' paradigm), comfort, pleasure, interest and confidence-in other words, positive affective engagement-according to the four welfare quality principles: adequate nutrition; adequate housing (environment, healthy animals); normal biological functioning and fitness; and normal behaviour display (a mental state that safeguards a high welfare status within the proper constraints of an effective dairy farm) $[16,18,19]$.

Interactions between handlers and lactating animals-such as dairy cattle, buffaloes, sheep and goats-are frequent, as conventional milking is usually performed more than once daily and still plays a very important role in affecting animals' performance and welfare status [20,21]. A farmer's intention should be to perform effective handling with minimal discomfort and stress for the dairy animals, which is achieved through pats, gentling, quiet movements and respect of animals' flight zone, since negative treatment generally impairs not only their growth development, reproductive performance and milk yield and quality, but also their health and welfare status $[10,20,22,23]$. Aversive handling is associated with improper management practices, and stressors such as shouting, pushes, slaps and hits, quick or unpredictable movements and the unnecessary utilization of electric prods can induce fear in animals, leading to an undesirable emotional state of suffering $[10,20]$. Fearful animals display increased levels of restlessness, observed as a high frequency of stepping and kicking and in their regular inspections and handling being strenuous and requiring more time, posing a risk to both human and animal safety [24]. Acute stress during milking can dramatically reduce the milk yield, due to an inhibition of the milk letdown through the secretion of catecholamines at the expense of oxytocin, leading to an impairment of milk ejection $[25,26]$. At the same time, continuous elevations 
of corticosteroids negatively affect the protein metabolism and hypothalamic-pituitaryadrenal (HPA) axis activation, leading to the release of pro-inflammatory cytokines [27].

Precision livestock farming (PLF) technologies have been developed with the intention to improve farm management and minimize aversive handling practices. According to Berckmans [28], a PLF system: (a) is a support tool that includes cameras, microphones and other sensors for tracking livestock, as well as computer software, and could improve the production efficiency through the adoption of electronic data collection, processing and application, but does not intend to replace the farmer; (b) is an animal-centric tool-the animal is the main part of the process; and (c) needs ideal conditions for the monitoring and control processes. For example, PLF systems have revolutionized the milking process through the introduction of automatic milking robots, leading to an improved quality and increased quantity of milk, while welfare status is maintained at high levels [29], since each individual animal can choose their preferred time of being milked [30]. PLF are real-time monitoring technologies with the core purpose to 'manage even the slightest manageable production unit's temporal variability (i.e., per animal approach)' [31,32]. They are frequently integrated with other new technologies in order to improve the human-livestock interactions, productivity and economical sustainability of modern farms [33]. In early years, milking robot machines were mostly used for indoor farming. However, automatic milking systems could also be applied in semi-grazing and pasturegrazing farms $[34,35]$.

Nowadays, consumers' concerns about the implications of mass-production systems on the welfare of dairy animals are continuously increasing, despite the fact that their level of knowledge about animal welfare issues, housing conditions and farm management is low [36]. According to the 'Farm to Fork Strategy' [37], farming activities are no longer perceived solely as food production systems, but are fundamental to safeguarding other concepts, such as food safety and quality, environmental protection and sustainability [38]. 'Social license' refers to the ongoing acceptance of farm practices and operating procedures by the general public and community [36] and is of vital importance for the continued support of dairy farms. Animal welfare parameters are increasingly affecting purchasers' choices, since welfare is considered a primal attribute of the food quality concept and animal-friendly products are nowadays considered safer, tastier, healthier, authentic, environmentally friendly and traditional by many consumers [38].

To meet community demands, targeted cognitive-behavioural training programs and specific protocols aimed at the handling improvement are therefore necessary in dairy farms in order to maintain an improved welfare status and production efficiency [39]. Undoubtedly, the attitudes and skills of the farmer and his/her familiarity with the animals are very important; however, there are also issues—-such as job satisfaction and motivation, working conditions and organisational policies and rules-that modify handling practices $[20,24]$. As indicated, participation in a training program focusing on handling and management reduces the probability of animals having their tails clamped, ears pinned back or being wide-eyed during the milking procedure [40]. That dairy products originate from improved welfare conditions can be further communicated to consumers by associated labelling and certification schemes, resulting in additional profit and possibly increased market share [36] An internationally accepted, transparent and traceable monitoring system is therefore necessary for the promotion of welfare-friendly products and the maintenance of dairy farming's 'social license' through the public's credibility and approval [36]. As indicated, younger consumers are more willing to pay for welfare-friendly products, and this fact is very important, since they will be the main formers of the food market in the future [36].

The aim of the present article is to review the existing literature concerning the interaction of the farmer with the most important dairy species, such as dairy cattle, buffaloes, sheep and goats, and its effects on their welfare, health and productivity. At the same time, the contribution of precision livestock farming systems in improving several aspects of ruminants' performance and well-being are evaluated. 


\section{Human-Dairy Animal Interaction}

\subsection{Dairy Cattle and Buffaloes}

The human-dairy cattle interaction and its effects on milk production and welfare status have been extensively examined [10,20,22,39]. Aversive handling and forceful, negative tactile interactions are generally associated with fear, high signs of nervousness, a reluctance to move to the milking parlour, baulking, an increased number of vocalizations or steps $[10,20,22]$, a decreased proportion of conceiving to the first insemination [20], a reduction of the milk yield and a deterioration of the milk quality (i.e., reduced protein and fat levels) $[10,20]$ in dairy cows. At the same time, aversively treated cows are more fearful of people and more difficult to handle, due to the increased secretion of cortisol and catecholamine as a result of excessive hypothalamo-pituitary-adrenal and sympathetic nervous system activity, respectively [24]. The high rates of agitation are assessed as an increased number of flinch, step and kick responses during milking process $[10,41]$. The ease of handling is affected by the nature of the human handling, and the response may be extended to other humans through the process of stimulus generalization [42].

The flight distance, defined as the distance to which an animal allows a moving person to approach, is also positively correlated with negative interactions at a moderate level $[20,43]$. Cows rapidly learn to avoid milkers associated with aversive handling, but this clear avoidance response may not indicate a level of fearfulness that negatively influences milk production [41]. As indicated, the flight or approach distance is in general not correlated with milk production [44]. Shouting and the utilization of electric prods appears to have the most intense aversion effects on the behaviour expressed by dairy cows, as cows needed more time and required more force to walk down an experimental race [45]. It is noteworthy also that non-producing periods, before maturity and during the dry period, play a very important role in the subsequent and lifelong advantages of a good relationship between the stockperson and dairy cows [46]. In addition, a positive farmer attitude towards his/her cows contributes to decreased rates of forceful and negative tactile interactions and an improved level of welfare $[10,20,24,43]$.

On the other hand, gently handled animals show a decreased avoidance of people [47] and improved fertility rates and udder health $[20,48]$. Furthermore, positive interactions (gentle touching, talking quietly, petting etc.) between the milker and dairy cattle result in a reduced display of kicking and stepping [49], which is associated with efficient handling [50], decreased heart rates [51] and milk cortisol levels [49] and an increased milk yield [52]. Pre-partum strategies result in a familiarization with the milking parlour and improve the welfare status of dairy cattle [53]. For example, stroking in certain areas, particularly the neck, decreases the display of avoidance behaviour and increases the approach behaviour of dairy cattle, providing evidence that positive tactile interactions with humans can make a positive impact on routine handling procedures [54,55]. This is more evident at earlier age, since a positive affiliative interaction with the caretaker leads to calmer dairy cattle in later life $[47,56]$. Becker and Lobato [57] reached to the conclusion that short daily positive interactions could improve the ease of handling of Zebu crossed (Nelore $x$ European) calves that are considered to have a more difficult temperament, leading to a reduction in labour costs and injuries.

Apart from human-animal interaction, genetic factors such as a breed's temperament could also affect cows' physiological and behavioural responses to milking, resulting in discrepancies both between and within breeds $[58,59]$. However, the subjection of nervous cows to pleasant treatment such as stroking and brushing at an early age could minimize stress responses displayed during milking, leading to an increase in the milk-flow rate and a decrease in the milking duration $[40,60]$. Moreover, dairy cattle that interact less frequently with humans have increased rates of 'flinch, step, kick' responses associated with a nervous milking temperament and are overall more difficult to handle compared to cows that are handled more often [61]. Even mild to non-detectable stressors such as an unfamiliar environment could induce increases in the vocalizations, heart rate and cortisol levels of dairy cattle [62]. 
Negative human-animal interaction during milking is positively correlated with kicking and restless stepping also in dairy buffaloes (with a correlation coefficient within 0.58 and 0.94$)[63,64]$. Buffaloes are more sensitive to stress stimuli than dairy cattle during milking, due to that fact that they are less intensively selected and domesticated compared to dairy cattle. At the same time, they are very consistent in their milking routine; therefore, even slight changes can influence their behaviour and performance during their milking [65]. As a result of stress, a secretion of adrenaline is induced, leading to a decrease in the oxytocin supply through vasoconstriction or the blockage of oxytocin receptors found on the myoepithelial cells of the udder alveoli, which is strongly associated with a reduced milk production [66]. On the other hand, positive interaction results in an improved milk production in dairy buffaloes $[64,67]$. The nervous temperament of buffaloes during milking could further lead to a reduced milk yield and fat content [68]. As indicated, the pre-partum habituation of buffalo heifers to the milking procedure reduces the level of restlessness, since fewer steps and kicks are observed during their milking compared to the control animals [67].

\subsection{Small Ruminants}

Scarce data exist on the effects of human-animal interaction on the productivity and welfare of sheep and goats. Aversive handling (slaps, pushes and loud shouting) leads to a reduction of the milk yield and an increase in kick responses during the milking of dairy ewes, although the milk flow rate was not affected [69]. Goats receiving aversive handling also showed increased salivary cortisol levels [70]. On the other hand, the development of a positive human-animal relationship results in ewes that are calmer and less reactive to the milking routine, with an improved welfare, more effective milk ejection and increased production [71]. Positive tactile interaction has been shown to improve the health status and increased heart girth of dairy goats and reduce their levels of stress [72]. In general, gentled animals show reduced flight distances, heart rates and cortisol levels in the presence of humans $[73,74]$. A positive affiliative bond with the caretaker during the early stages of life in lambs leads to positive behavioural and physiological consequences and calmer animals at adolescence [75-77].

In contrast, no differences in the milk yield, milk quality and kick number during milking were observed between ewes classified as nervous or calm based on their temperament, although nervous ewes were less reluctant to enter the milking parlour, and the attachment of the milking cups to them took a longer time than it did to the calm ewes [78]. Furthermore, Napolitano et al. [79] observed that the positive attitude of a farmer towards their sheep resulted in positive interactions and was negatively correlated with the flight distance in the pen.

\section{Precision Livestock Farming (PLF) Advancements in Dairy Production}

\subsection{Dairy Cattle}

PLF systems have been developed to assess the welfare and health status of dairy animals by reducing labour demands. In detail, they aim at the fully automated continuous monitoring of ruminants, emphasizing individuality, by utilizing technological and computer innovations as part of the production process. Sensing devices refer to almost any sensor that might be utilized and applied within any step of the production process (e.g., image and sound, temperature, pressure, blood and urine analysis sensors, etc.). PLF systems' function is mainly based on monitoring the animals' behaviours (e.g., feeding, drinking, lying, etc.) and behavioural changes due to external factors such as housing conditions (e.g., temperature and humidity variations and air flow), or biological changes (e.g., oestrus, calving and diseases) that greatly affect the animals' health and welfare status [80,81]. When such behavioural changes are detected, the system triggers a warning signal, enabling the farmer to take immediate action, and leading to an early problem diagnosis and solution or an immediate housing practices assessment $[82,83]$. At the same time, the farmer can monitor the animals' everyday lives irrespective of the size of the 
herd [5]. Therefore, the application of these systems can potentially improve animals health and welfare, the quality and quantity of the end-product and enhance the economic viability of the unit.

Stygar et al. [84] reported that 129 commercial applications from 67 different providers are available in the dairy cattle industry today. These technologies include: milking robot; accelerometer-based sensors for monitoring the health status; load cell systems combined with radio-frequency identification (RFID) technologies (i.e., collar-, leg-, ear- and haltermounted sensors) for rumination time recording, heat stress detection, movement tracking, individual identification and lameness detection; boluses used for body temperature monitoring, $\mathrm{pH}$ analysis, rumen activity and individual identification; complex camera-based systems for body temperature monitoring (i.e., thermal cameras), body condition scoring and monitoring feeding and drinking behaviour; GPS sensors for monitoring activity; sound analysis systems; and mobile applications for body condition scoring and weight estimation (Table 1). However, only $14 \%$ of the commercially available systems have been validated externally, undermining their credibility [84]. For example, false alerts of modern sensor technology could minimize the benefits stemming from PLF's application. The lack of validation and unfamiliarity of PLF technology are the main obstacles to dairy producers adopting these systems on farms.

Table 1. Application of precision livestock farming advancements in dairy cattle.

\begin{tabular}{|c|c|c|}
\hline Parameter of Interest & Applied Technology & Reference \\
\hline Feeding & Precision concentrate rationing & {$[85]$} \\
\hline Herd management & Wireless sensing & {$[86]$} \\
\hline Oestrus detection & $\begin{array}{c}\text { Pedometers } \\
\text { Animal-mounted detectors } \\
\text { Camera-based systems } \\
\text { Infrared sensors } \\
\text { Herd navigator }\end{array}$ & $\begin{array}{c}{[87-90]} \\
{[91-97]} \\
{[97,98]} \\
{[99,100]} \\
{[101-103]}\end{array}$ \\
\hline Lameness detection & $\begin{array}{l}\text { Neural network models } \\
\text { Internet of things (IoT) } \\
\text { Mount detectors } \\
\text { Camera-based systems }\end{array}$ & $\begin{array}{c}{[104]} \\
{[105,106]} \\
{[106-109]} \\
{[110-116]}\end{array}$ \\
\hline Mastitis detection & $\begin{array}{l}\text { Milk's electrical conductivity analysis sensors } \\
\text { Milk colour analysis sensors } \\
\text { Lactate dehyfrogenase analysis sensors } \\
\text { Various sensors installed on milking robot for } \\
\text { measuring milk yield, body weight, lactose, fat } \\
\text { and protein percentages, blood percentage and } \\
\text { somatic cells counts } \\
\text { Infrared sensors and thermal cameras }\end{array}$ & $\begin{array}{c}{[35,121-123]} \\
{[124,125]}\end{array}$ \\
\hline Health status and behaviour & $\begin{array}{l}\text { Various animal-mounted wireless sensors } \\
\text { Biometric sensors }\end{array}$ & $\begin{array}{c}{[126]} \\
{[127,128]}\end{array}$ \\
\hline $\begin{array}{l}\text { Rumination and health } \\
\text { status monitoring }\end{array}$ & $\begin{array}{l}\text { Microphones } \\
\text { Accelerometers }\end{array}$ & $\begin{array}{l}{[129,130]} \\
{[131,132]}\end{array}$ \\
\hline Individual identification & $\begin{array}{c}\text { Drones } \\
\text { Camera-based monitoring }\end{array}$ & $\begin{array}{c}{[133]} \\
{[134-137]}\end{array}$ \\
\hline $\begin{array}{l}\text { Body weight and body condition } \\
\text { score estimation }\end{array}$ & $\begin{array}{c}\text { Camera-based monitoring } \\
\text { Ultrasonic sensors } \\
\text { Thermal cameras }\end{array}$ & $\begin{array}{c}{[134-137]} \\
{[138]} \\
{[138-140]}\end{array}$ \\
\hline
\end{tabular}

\subsubsection{Assessment of Health Status}

The most common health issues in the dairy industry are mastitis and lameness. The presence of these diseases can have a serious impact on a unit's everyday processes, damaging the health and welfare of the animals and the production quality and quantity-hence negatively affecting the economy of the unit [141]. The economic loss can be traced to a decreased milk yield $[107,142,143]$, reduced reproductive performance $[144,145]$ and increased culling 
risk [146]. A variety of PLF technologies have been introduced for the monitoring and early detection of such problems [4].

\section{Lameness Detection}

Lameness is among the top three health-related causes of economic loss in the dairy industry. Animals suffering from lameness demonstrate a reduced mobility, milk yield, reproductive ability and loss of body condition and feel intense pain [144]. To date, the diagnosis of the disease relies mostly on visual observation, which is time-consuming and sensitive to variations between the observers, and it is often omitted, resulting in production losses and increased treatment costs [147]. Therefore, it is essential to detect lameness at an early stage for effective treatment and disease progress prevention.

Several models have already been developed for lameness detection by monitoring individual animals' locomotion and walking patterns and have been proven to be very promising for assessing the problem. Pastel and Kujala [104] developed a four-balance probabilistic neural network model based on weekly measurements of the leg load (i.e., leg weight pressure) of 73 cows over a 5 month period. They reported a score of 100\% lameness validation and $96.2 \%$ classification success. Viazzi et al. [111] developed a camera-based model that detects lameness by monitoring individual animals' locomotion and walking patterns. Using the population approach, they reported a correct classification score of $76 \%, 83 \%$ and $22 \%$ of true positive and false positive rate, respectively. However, when the individual monitoring approach was used, the classification accuracy was considerably increased by $10 \%$ (i.e., up to $91 \%$ ) and the false positive rate was decreased to $6 \%$, implying that individual monitoring is the most effective way to detect lameness compared with the population threshold. Romanini et al. [112] developed a model based on a 3D video data analysis, and successfully classified $75.7 \%$ of lameness cases with an accuracy of $91.3 \%$. However, the level of misclassification of the systems led to multiple false alarm signals, and thus, further research is needed for the development of a commercial application. Thermal imaging can also be used as a diagnostic tool for the detection of temperature changes that are often related with an infection or inflammation of the hooves and lameness [148].

\section{Mastitis Detection}

Milking dairy cows has been a common process since at least $3100 \mathrm{BC}$, and bovine mastitis disease has probably existed since the same era [149]. However, a complete understanding of the disease only came alongside the invention of microscopes that allowed the detection and analysis of microorganisms, and Breed and Brew [150] first reported the existence of streptococci bacteria in milk. Since then, mastitis has become one of the most referenced research areas, emphasizing its effects on public health [149], the degradation of milk characteristics and milk quality [151], animal welfare deterioration [152] and mastitis' negative impact on the economy of units [153].

During the 21st century, technological advancements have allowed scientists to develop various models and PLF applications, improving animals' health and welfare and at the same time bringing the farmer closer to the individual animals [154]. Since milking robots' introduction in the managerial process of farms, a variety of automatic mastitis early detection systems have been developed [121]. These systems consist of at least two basic elements: (a) a combination of sensors for data collection and (b) the development of algorithmic models that translate the data into alerts alongside a decision support/making system [155]. The most common variables analysed and evaluated for the detection of mastitis include: milk's electrical conductivity [117,118]; milk's colour [119]; lactate dehydrogenase [120]; milk yield, body weight, lactose, fat and protein percentages; the blood percentage; and somatic cell counts (SCC) during automatic milking [121,123]. Furthermore, PLF technologies that are under development include infra-red and thermal cameras [124,125], biometric sensors (either invasive or non-invasive) for real-time individual health and behaviour monitoring [127]. Therefore, today's farmers can choose between a variety of systems to fit their individual needs, simplify their everyday processes, cut 
down their workloads, improve the welfare of their animals and increase the sustainability of their units.

\subsection{Small Ruminants}

Small ruminants are often managed as a flock/herd, allowing only average welfare states to be considered. Innovative technologies provide a unique opportunity to monitor and improve welfare management from the farm-level manual to automated or semiautomated assessment and management at an individual level, leading to a reduction along the value chain (https: / / techcare-project.eu, accessed on 7 September 2021) of on-farm labour and veterinary care costs [156]. However, PLF technologies and applications are not common in small ruminant farming, since most sheep and goat farmers' acceptance and adaptation of the new technologies remains considerably low, and most technologies and PLF applications are therefore mainly used for research purposes [33].Small ruminant farms are often located in remote and mountainous areas, where infrastructure and services are poorly developed. High equipment costs, a lack of demonstration and specific training and low education levels also contribute to the delay of PLF's implementation. At the same time, there are also practical issues related to the productive cycle of small ruminants that present a barrier to the application of PLF advancements. For example, although oestrus detection is of vital importance in dairy cattle and the main driver of PLF applications for cows, it is not such a priority for small ruminant farmers [80]. According to Wishart [157], PLF technologies would be more attractive to sheep and goat farmers if researchers focused on demonstrating the beneficial impact these systems have on welfare and efficiency, leading to more sustainable and profitable units. Table 2 presents PLF applications used in research for minimizing or even solving a variety of different problems in contemporary sheep and goat farms.

Table 2. Application of precision livestock farming advancements to sheep and goats.

\begin{tabular}{|c|c|c|}
\hline Parameter of Interest & Applied Technology & Reference \\
\hline \multirow{2}{*}{ Grazing and ruminating behaviour } & Animal-mounted accelerometer/gyroscope sensor & [158] \\
\hline & Animal-mounted tri-axial accelerometer loggers & [159] \\
\hline \multirow{3}{*}{ Resting, grazing and searching behaviours } & Animal-mounted tri-axial accelerometer loggers & [159] \\
\hline & GIS systems & [160] \\
\hline & Animal-mounted GPS sensors & [160-163] \\
\hline \multirow{2}{*}{ Animal tracking } & Animal-mounted GPS sensors & [160-163] \\
\hline & Animal-mounted tri-axial accelerometer loggers & [164] \\
\hline Sexual behaviour of rams & Animal mounted accelerometers & [165] \\
\hline \multirow{5}{*}{ Feeding behaviour } & Camera-based analysis & [161] \\
\hline & Microphones & {$[161]$} \\
\hline & Animal-mounted gyroscopes & [161] \\
\hline & Animal-mounted accelerometers & {$[161,166,167]$} \\
\hline & GPS sensors & [168] \\
\hline \multirow{2}{*}{ Oestrus detection } & Alpha-D detector & {$[169,170]$} \\
\hline & Infrared thermography & {$[171,172]$} \\
\hline \multirow{2}{*}{ Lameness detection } & Infrared thermography & [173] \\
\hline & Hoof weigh crate with four load platforms & [174] \\
\hline Lambing detection & Animal-mounted temperature sensors & [175] \\
\hline Health status detection & Implanted sensors (heart rate and body temperature) & [176] \\
\hline \multirow{4}{*}{ Individual identification } & Injectable transponders & {$[177,178]$} \\
\hline & RFID sensors & {$[156,179,180]$} \\
\hline & Endoruminal bolus & {$[180,181]$} \\
\hline & Drones-image analysis & [182] \\
\hline Age identification & Sound recorders analysis & [183] \\
\hline Flock monitoring & Drones-image analysis & {$[182,184]$} \\
\hline Weight monitoring & Automatic weigh-crates & [157] \\
\hline \multirow{3}{*}{ Standing/lying behaviour monitoring } & Camera-based analysis & [185] \\
\hline & Ultra-wide band real-time location & [185] \\
\hline & Animal mounted accelerometers & [186] in goats \\
\hline Flock management & $\begin{array}{l}\text { Virtual fence (i.e., animal-mounted collars embedded with electromagnetic } \\
\text { transmitters and ground-installed receivers and sound speakers) }\end{array}$ & [187-192]; [193] in goats \\
\hline
\end{tabular}


PLF's adoption in commercial applications is more common in intensive large-scale farms. Although several sensors, injectable devices, ear tags, rumen boluses, pedometers, collars and infrared cameras have been developed, the most common PLF application for sheep and goats is to install sensors in the milking parlour. According to Alejandro [194], the most ordinary automations applied to small ruminants include:

(a) Automatic vacuum shut-off (AVSO), which is a mechanism, either time- or flowbased, that prevents overmilking and its negative impact on the animals' health and welfare. Therefore, it improves the sanitary status of the milking parlour, while at the same time reducing the labour required. Bueso-Ródenas et al. [195] and Romero et al. [196] reported that the flow-based AVSO is better than manual milking, as the same amounts of milk were extracted in shorter time intervals. Furthermore, they proposed that the best combinations of the flow limit (i.e., the time interval during which the vacuum shut-off is activated) and delay time (i.e., the minimum flow set, such that below that point the vacuum shut-off is activated) for sheep are $150 \mathrm{~g} / \mathrm{min}$ and $20 \mathrm{~s}$ or $200 \mathrm{~g} / \mathrm{min}$ and $10 \mathrm{~s}$, respectively, and that for goats it is $100-150 \mathrm{~g} / \mathrm{min}$ and $10 \mathrm{~s}$, respectively.

(b) Milk meter and flow indicators, which are sensors that allow the monitoring of the milk flow of every individual animal. Electronic milk meter measurements are based on the combined data of infrared and conductivity sensors and/or a volume measuring chamber [194]. The data is analysed and presented on the display of a personal computer. Furthermore, electronic milk meters have the ability to sample and analyse milk, providing information on the animals' health status [194,197]. Therefore, milk and flow meter applications are an essential decision-making tool for the farmer.

(c) Electronic identification assessment, which is performed by various sensor-based applications such as injectable transponders [177,178], RFID [156,179,180], endoruminal boluses [180,181] and drones [182]. These systems carry individual information concerning the age, weight, gender, health status and milk flow of every animal. The producer can keep a catalogue of all individual animals in the flock, and thus, they are a very useful long-term decision-making tool. It should be noted that to date mostly the RFID technology is used, as the transmitters attached on ear tags or foot are read from the receiver installed in the milking parlour and therefore the data flow can be accessed remotely in real time.

(d) Automatically operated sorting gate and weighing scale systems are connected to a flock management software, which sorts the animals into groups or modifies existing groups and separates the animals in need of treatment. These systems minimise both the labour and time spent regrouping and relocating the animals [194], practices that are commonly applied to obtain uniformity within groups in terms of milk yield [198].

Although small ruminant farmers acknowledge the advantages deriving from the application of PLF techniques, a resistance to their regular adoption due to economic and cultural constraints, poor technological infrastructures (electricity, telephone and internet networks) and a lack of information and competence is observed [80,199]. At the same time, sensor manufacturing companies are not interested in the development of sensors that can be used on small ruminants due their high device cost (miniaturization, decreased manufacturing numbers), the large number of animals per farm and the low individual profit compared to dairy cattle [80]. However, European agricultural policy that is affected by concepts such as climatic change, global warming, green economy, animal welfare and antibiotic resistance could influence farming practices and stimulate a wider adoption of PLF systems in the near future [33].

\section{Conclusions}

The existence of a correlation between handling, productivity and welfare in commercial dairy farms highlights the necessity of high-quality farm management. Precision livestock farming systems appear to provide an alternative, since they could serve as 
useful support tools for the farmer's decision making and improve the sustainability and competitiveness of dairy farms through the implementation of automated procedures that minimize the labour demand, animal disturbances and environmental impact. Sensor applications are expected to be continually developed with further advancements with regard to their size, energy management and data transmission protocols. The software used in PLF systems must not be complex and needs to be designed in a format that farmers and staff can easily understand, to predict risks over the short term and increase productivity and profitability in livestock over the long term. However, even with technological innovations that enable improved precision farming and automation, efficient handling is still fundamental to improving farm animals' welfare and its associated health and production benefits. Especially in small ruminants, PLF applications are still scarce, and training programs targeted at the improvement of daily routine practices are therefore necessary in order to sustain high welfare and production levels.

Author Contributions: Conceptualization, P.S. and E.S.; writing-original draft preparation, P.S. and C.T.; writing-review and editing, P.S., E.S. and O.T.; supervision, P.S. All authors have read and agreed to the published version of the manuscript.

Funding: This research received no external funding.

Institutional Review Board Statement: Not applicable.

Informed Consent Statement: Not applicable.

Conflicts of Interest: The authors declare no conflict of interest.

\section{References}

1. United Nations, Department of Economic and Social A Airs Population Division. World Population Prospects 2019: Highlights; United Nations, Department of Economic and Social A Airs Population Division: New York, NY, USA, 2019.

2. Hartung, J.; Banhazi, T.; Vranken, E.; Guarino, M. European farmers' experiences with Precision Livestock Farming systems. Anim. Front. 2017, 7, 38-44. [CrossRef]

3. Berckmans, D. Precision livestock farming technologies for welfare management in intensive livestock systems. Rev. Sci. Tech. 2014, 33, 189-196. [CrossRef]

4. Mottram, T. Animal broad invited review: Precision livestock farming for dairy cows with a focus on oestrus detection. Animal 2016, 10, 1575-1584. [CrossRef]

5. Norton, T.; Chen, C.; Larsen, M.L.V.; Berckamns, D. Review: Precision livestock farming: Building 'digital representations' to bring the animals closer to the farmer. Animal 2019, 13, 3009-3017. [CrossRef]

6. Zucali, M.; Lovareli, D.; Celozzi, S.; Bacenetti, J.; Sandrucci, A.; Bava, L. Management options to reduce the environmental impact of dairy goat milk production. Livest. Sci. 2020, 231, 103888. [CrossRef]

7. Gieseke, D.; Lambertz, C.; Gauly, M. Relationship between herd size and measures of animal welfare on dairy cattle farms with freestall housing in Germany. J. Dairy Sci. 2018, 101, 7397-7411. [CrossRef] [PubMed]

8. Beggs, D.S.; Jongman, E.C.; Hemsworth, P.H.; Fisher, A.D. The effects of herd size on the welfare of dairy cows in a pasture-based system using animal-and resource-based indicators. J. Dairy Sci. 2019, 102, 3406-3420. [CrossRef] [PubMed]

9. Seabrook, M.F. The psychological interaction between the stockman and his animals and its influence on performance of pigs and dairy cows. Vet. Rec. 1984, 115, 84-87. [CrossRef] [PubMed]

10. Breuer, K.; Hemsworth, P.H.; Barnett, J.L.; Matthews, L.R.; Coleman, G.J. Behavioural response to humans and the productivity of commercial dairy cows. Appl. Anim. Behav. Sci. 2000, 66, 273-288. [CrossRef]

11. Vasseur, E. Animal behavior and well-being symposium: Optimizing outcome measures of welfare in dairy cattle assessment. J. Anim. Sci. 2017, 95, 1365-1371. [CrossRef] [PubMed]

12. Cornish, A.; Raubenheimer, D.; McGreevy, P. What we know about the public's level of concern for farm animal welfare in food production in developed countries. Animals 2016, 6, 74. [CrossRef] [PubMed]

13. Hemsworth, P.H.; Mellor, D.J.; Cronin, G.M.; Tilbrook, A.J. Scientific assessment of animal welfare. N. Z. Vet. J. 2015, 63, 24-30. [CrossRef]

14. Désiré, L.; Boissy, A.; Veissier, I. Emotions in farm animals: A new approach to animal welfare in applied ethology. Behav. Processes 2002, 60, 165-180. [CrossRef]

15. Barrell, G.K. An appraisal of methods for measuring welfare of grazing ruminants. Front. Vet. Sci. 2019, 6, 289. [CrossRef]

16. Mellor, D.J. Updating animal welfare thinking: Moving beyond the "Five Freedoms" towards "a Life Worth Living". Animals 2016, 6, 21. [CrossRef]

17. Fraser, D. Assessing animal welfare at the farm and group level: The interplay of science and values. Anim. Welf. 2003, 12, 433-443. 
18. Mellor, D.J.; Beausoleil, N.J. Extending the 'Five Domains' model for animal welfare assessment to incorporate positive welfare states. Anim. Welf. 2015, 24, 241. [CrossRef]

19. Mellor, D.J.; Beausoleil, N.J.; Littlewood, K.E.; McLean, A.N.; McGreevy, P.D.; Jones, B.; Wilkins, C. The 2020 five domains model: Including human-animal interactions in assessments of animal welfare. Animals 2020, 10, 1870. [CrossRef]

20. Hemsworth, P.H.; Coleman, G.J.; Barnett, J.L.; Borg, S. Relationships between human-animal interactions and productivity of commercial dairy cows. J. Anim. Sci. 2000, 78, 2821-2831. [CrossRef] [PubMed]

21. Szücs, E.; Geers, R.; Sossidou, E.N. Stewardship, stockmanship and sustainability in animal agriculture. Asian-Australas. J. Anim. Sci. 2009, 22, 1334-1340. [CrossRef]

22. Rushen, J.; de Passille, A.M.B.; Munksgaard, L. Fear of people by cows and effects on milk yield, behavior and heart rate at milking. J. Dairy Sci. 1999, 82, 720-727. [CrossRef]

23. Rushen, J.; Taylor, A.A.; De Passillé, A.M. Domestic animals' fear of humans and its effect on their welfare. Appl. Anim. Behav. Sci. 1999, 65, 285-303. [CrossRef]

24. Hemsworth, P.H. Human-animal interactions in livestock production. Appl. Anim. Behav. Sci. 2003, 81, 185-198. [CrossRef]

25. Lefcourt, A.M.; Akers, R.M. Small increases in peripheral noradrenaline inhibit the milk-ejection response by means of a peripheral mechanism. J. Endocrinol. 1984, 100, 337-344. [CrossRef] [PubMed]

26. Bruckmaier, R.M.; Blum, J.W. Oxytocin release and milk removal in ruminants. J. Dairy Sci. 1998, 81, 939-949. [CrossRef]

27. Ciliberti, M.G.; Albenzio, M.; Inghese, C.; Santillo, A.; Marino, R.; Sevi, A.; Caroprese, M. Peripheral blood mononuclear cell proliferation and cytokine production in sheep as affected by cortisol level and duration of stress. J. Dairy Sci. 2017, 100, 750-756. [CrossRef]

28. Berckmans, D. Automatic on-line monitoring of animals by precision livestock farming. In Animal Production in Europe: The Way Forward in a Changing World, in between Congress of the ISAH; Madec, F., Clement, G., Eds.; ISAH: Saint-Malo, France, 2004; pp. 27-30.

29. John, A.J.; Clark, C.E.F.; Freeman, M.J.; Kerrisk, K.L.; Garcia, S.C.; Halachmi, I. Review: Milking robot utilization, a successful precision livestock farming evolution. Animal 2016, 10, 1484-1492. [CrossRef] [PubMed]

30. Kuipers, A.; Rossing, W. Robotic milking of dairy cows. In Progress in Dairy Science, 1st ed.; Philips, C.J.C., Ed.; CABI Publishing: Wallingford, UK, 1996; pp. 263-280.

31. Halachmi, I.; Guarino, M. Editorial: Precision livestock farming: A 'per animal' approach using advance monitoring technologies. Animal 2016, 10, 1482-1483. [CrossRef] [PubMed]

32. Halachmi, I.; Guarino, M.; Bewley, J.; Pastell, M. Smart Animal Agriculture: Application of real-time sensors to improve animal well-being and production. Annu. Rev. Anim. Biosci. 2018, 7, 403-425. [CrossRef]

33. Vaintrub, M.O.; Levit, H.; Chincarini, M.; Fusaro, I.; Giammarco, M.; Vignola, G. Precision livestock farming, automats and new technologies: Possible applications in extensive dairy sheep farming. Animal 2021, 15, 100143. [CrossRef]

34. Greenall, R.; Warren, E.; Warren, M.; Meijering, A.; Hogeveen, H.; de Koning, C. Integrading automatic milking installations (AMIS) into grazing systems-Lessons from Australia. In Automatic Milking: A Better Understanding, 1st ed.; Meijering, A., Hogeveen, H., De-Koning, C., Eds.; Wageningen Academic Publishers: Wageningen, The Netherlands, 2004; pp. 273-279. [CrossRef]

35. Woolford, M.; Claycomb, R.; Jago, J.; Davis, K.; Ohnstad, I.; Wieliczko, R.; Copeman, P.; Bright, K. Automatic dairy farming in New Zealand using extensive grazing systems. In Automatic Milking: A Better Understanding, 1st ed.; Meijering, A., Hogeveen, H., De-Koning, C., Eds.; Wageningen Academic Publishers: Wageningen, The Netherlands, 2004; pp. 280-285. [CrossRef]

36. Alonso, M.E.; González-Montaña, J.R.; Lomillos, J.M. Consumers' concerns and perceptions of farm animal welfare. Animals 2020, 10, 385. [CrossRef]

37. COM Final Communication from the Commission to the European Parliament, the Council, the European Economic and Social Committee and the Committee of the Regions, Brussels. Available online: https://europa.eu/eurobarometer/surveys/detail/20 96 (accessed on 20 May 2020).

38. European-Commission. Attitudes of EU Citizens towards Animal Welfare, Report; Special Eurobarometer 442; European Commission: Brussels, Belgium, 2016; p. 84.

39. Napolitano, F.; Bragaglio, A.; Sabia, E.; Serrapica, F.; Braghieri, A.; De Rosa, G. The human-animal relationship in dairy animals. J. Dairy Res. 2020, 87, 47-52. [CrossRef] [PubMed]

40. Kutzer, T.; Steilen, M.; Gygax, L.; Wechsler, B. Habituation of dairy heifers to milking routine-Effects on human avoidance distance, behavior, and cardiac activity during milking. J. Dairy Sci. 2015, 98, 5241-5251. [CrossRef] [PubMed]

41. Munksgaard, L.; de Passille, A.M.; Rushen, J.; Herskin, M.S.; Kristensen, A.M. Dairy cows' fear of people: Social learning, milk yield and behavior at milking. Appl. Anim. Behav. Sci. 2001, 73, 15-26. [CrossRef]

42. Breuer, K.; Hemsworth, P.H.; Coleman, G.J. The effect of positive or negative handling on the behavioural and physiological responses of nonlactating heifers. Appl. Anim. Behav. Sci. 2003, 84, 3-22. [CrossRef]

43. Waiblinger, S.; Menke, C.; Coleman, G. The relationship between attitudes, personal characteristics and behaviour of stockpeople and subsequent behaviour and production of dairy cows. Appl. Anim. Behav. Sci. 2002, 79, 195-219. [CrossRef]

44. Purcell, D.; Arave, C.W.; Walters, J.L. Relationship of three measures of behavior to milk production. Appl. Anim. Behav. Sci. 1988, 21, 307-313. [CrossRef]

45. Pajor, E.A.; Rushen, J.; De Passillé, A.M.B. Aversion learning techniques to evaluate dairy cattle handling practices. Appl. Anim. Behav. Sci. 2000, 69, 89-102. [CrossRef] 
46. Uetake, K.; Morita, S.; Hoshiba, S.; Tanaka, T. Flight distance of dairy cows and its relationship to daily routine management procedures and productivity. Anim. Sci. J. 2002, 73, 279-285. [CrossRef]

47. Lensink, B.J.; Fernandez, X.; Boivin, X.; Pradel, P.; Le Neindre, P.; Veissier, I. The impact of gentle contacts on ease of handling, welfare, and growth of calves and on quality of veal meat. J. Anim. Sci. 2000, 78, 1219-1226. [CrossRef]

48. Ivemeyer, S.; Knierim, U.; Waiblinger, S. Effect of human-animal relationship and management on udder health in Swiss dairy herds. J. Dairy Sci. 2011, 94, 5890-5902. [CrossRef]

49. Bertenshaw, C.E.; Rowlinson, P. Exploring heifers' perception of 'positive' treatment through their motivation to pursue a retreated human. Anim. Welf. 2008, 17, 313-319.

50. Lindahl, C.; Pinzke, S.; Herlin, A.; Keeling, L.J. Human-animal interactions and safety during dairy cattle handling-Comparing moving cows to milking and hoof trimming. J. Dairy Sci. 2016, 99, 2131-2141. [CrossRef]

51. Waiblinger, S.; Menke, C.; Korff, J.; Bucher, A. Previous handling and gentle interactions affect behaviour and heart rate of dairy cows during a veterinary procedure. Appl. Anim. Behav. Sci. 2004, 85, 31-42. [CrossRef]

52. Hanna, D.; Sneddon, I.A.; Beattie, V.E.; Breuer, K. Effects of the stockperson on dairy cow behavior and milk yield. Anim. Sci. 2006, 82, 791-797. [CrossRef]

53. Das, K.S.; Das, N. Pre-partum udder massaging as a means for reduction of fear in primiparous cows at milking. Appl. Anim. Behav. Sci. 2004, 89, 17-26. [CrossRef]

54. Schmied, C.; Boivin, X.; Wailblinger, S. Stroking different body regions of dairy cows: Effects on avoidance and approach behavior toward humans. J. Dairy Sci. 2008, 91, 596-605. [CrossRef] [PubMed]

55. Schmied, C.; Boivin, X.; Scala, S.; Waiblinger, S. Effect of previous stroking on reactions to a veterinary procedure. Interact. Stud. 2010, 11, 467-481. [CrossRef]

56. Waiblinger, S.; Boivin, X.; Pedersen, V.; Tosi, M.V.; Janczak, A.M.; Visser, E.K.; Jones, R.B. Assessing the human-animal relationship in farmed species: A critical review. Appl. Anim. Behav. Sci. 2006, 101, 185-242. [CrossRef]

57. Becker, B.G.; Lobato, J.P. Effect of gentle handling on the reactivity of zebu crossed calves to humans. Appl. Anim. Behav. Sci. 1997, 53, 219-224. [CrossRef]

58. Grandin, T. Assessment of stress during handling and transport. J. Anim. Sci. 1997, 75, 249-257. [CrossRef]

59. Sutherland, M.A.; Rogers, A.R.; Verkerk, G.A. The effect of temperament and responsiveness towards humans on the behavior, physiology and milk production of multiparous dairy cows in a familiar and novel milking environment. Physiol. Behav. 2012, 107, 329-337. [CrossRef]

60. Sutherland, M.A.; Huddart, F.J. The effect of training first-lactation heifers to the milking parlor on the behavioral reactivity to humans and the physiological and behavioral responses to milking and productivity. J. Dairy Sci. 2012, 95, 6983-6993. [CrossRef] [PubMed]

61. Hemsworth, P.H.; Barnett, J.L.; Tilbrook, A.J.; Hansen, C. The effects of handling by humans at calving and during milking on the behavior and milk cortisol concentrations of primiparous dairy cows. Appl. Anim. Behav. Sci. 1989, 22, 313-326. [CrossRef]

62. Rushen, J.; Munksgaard, L.; Marnet, P.G.; De Passillé, A.M. Human contact and the effects of acute stress on cows at milking. Appl. Anim. Behav. Sci. 2001, 73, 1-14. [CrossRef]

63. Saltalamacchia, F.; Tripladi, C.; Castellano, A.; Napolitano, F.; Musto, M.; De Rosa, G. Human and animal behaviour in dairy buffalo at milking. Anim. Welf. 2007, 16, 139-142.

64. Napolitano, F.; Serrapica, F.; Braghieri, A.; Masucci, F.; Sabia, E.; De Rosa, G. Human-animal interactions in dairy buffalo farms. Animals 2019, 9, 246. [CrossRef]

65. Thomas, C.S. Milking Management of Dairy Buffaloes. Ph.D. Thesis, Swedish University of Agricultural Sciences, Uppsala, Sweden, 2004.

66. Thomas, C.S.; Borghese, A.; d'Elisi, M.G. Physiology of milk ejection. In Milking Management of Dairy Buffaloes; Rasmussen, M.D., Thomas, C.S., Borghese, A., Eds.; Bulletin of the International Dairy Federation n. 426; Bulletin of the International Dairy Federation: Bruxelles, Belgium, 2008; pp. 31-35.

67. Polikarpus, A.; Napolitano, F.; Grasso, F.; Di Palo, R.; Zicarelli, F.; Arney, D.; De Rosa, G. Effect of pre-partum habituation to milking routine on behavior and lactation performance of buffalo heifers. Appl. Anim. Behav. Sci. 2014, 161, 1-6. [CrossRef]

68. de Carvalhal, M.V.L.; Sant'Anna, A.C.; Pascoa, A.G.; Jung, J.; da Costa, M.J.R.P. The relationship between water buffalo cow temperament and milk yield and quality traits. Livest. Sci. 2017, 198, 109-114. [CrossRef]

69. Simitzis, P.; Seferlis, I.; Goliomytis, M.; Bizelis, I.; Politis, I. Handling and milking frequency affect milk yield and behavior in dairy ewes. Small Rumin. Res. 2021, 198, 106351. [CrossRef]

70. Baxter, E.M.; Mulligan, J.; Hall, S.A.; Donbavand, J.E.; Palme, R.; Aldujaili, E.; Zanella, A.J.; Dwyer, C.M. Positive and negative gestational handling influences placental traits and mother-offspring behavior in dairy goats. Physiol. Behav. 2016, 157, 129-138. [CrossRef] [PubMed]

71. Dimitrov, I.; Djorbineva, M. Assessment of welfare, functional parameters of the udder, milk productive and reproductive traits in dairy ewes of different temperament. Bulg. J. Agric. Sci. 2003, 9, 707-711.

72. Jackson, K.M.A.; Hackett, D. A note: The effects of human handling on heart girth, behaviour and milk quality in dairy goats. Appl. Anim. Behav. Sci. 2007, 108, 332-336. [CrossRef]

73. Hargreaves, A.L.; Hutson, G.D. The effect of gentling on heart rate, flight distance and aversion of sheep to a handling procedure. Appl. Anim. Behav. Sci. 1990, 26, 243-252. [CrossRef] 
74. Caroprese, M.; Napolitano, F.; Boivin, X.; Albenzio, M.; Annicchiarico, G.; Sevi, A. Development of affinity to the stockperson in lambs from two breeds. Physiol. Behav. 2012, 105, 251-256. [CrossRef] [PubMed]

75. Nowak, R.; Boivin, X. Filial attachment in sheep: Similarities and differences between ewe-lamb and human-lamb relationships. Appl. Anim. Behav. Sci. 2015, 164, 12-28. [CrossRef]

76. Tallet, C.; Veissier, I.; Boivin, X. Human contact and feeding as rewards for the lamb's affinity to their stockperson. Appl. Anim. Behav. Sci. 2005, 94, 59-73. [CrossRef]

77. Tallet, C.; Veissier, I.; Boivin, X. How does the method used to feed lambs to modulate their affinity to their human caregiver? Appl. Anim. Behav. Sci. 2009, 119, 56-65. [CrossRef]

78. Murray, T.L.; Blache, D.B.; Bencini, R. The selection of dairy sheep on calm temperament before milking and its effect on management and milk production. Small Rumin. Res. 2009, 87, 45-49. [CrossRef]

79. Napolitano, F.; De Rosa, G.; Girolami, A.; Scavone, M.; Braghieri, A. Avoidance distance in sheep: Test-retest reliability and relationship with stockmen attitude. Small Rumin. Res. 2011, 99, 81-86. [CrossRef]

80. Caja, G.; Castro-Costa, A.; Salama, A.A.; Oliver, J.; Baratta, M.; Ferrer, C.; Knight, C.H. Sensing solutions for improving the performance, health and wellbeing of small ruminants. J. Dairy Res. 2020, 87, 34-46. [CrossRef]

81. Lovarelli, D.; Bacenetti, J.; Guarino, M. A review on dairy cattle farming: Is precision livestock farming the compromise for an environmental, economic and social sustainable production? J. Clean. Prod. 2020, 262, 121409. [CrossRef]

82. Caja, G.; Castro-Costa, A.; Knight, C.H. Engineering to support wellbeing of dairy animals. J. Dairy Res. 2016, 83, 136-147. [CrossRef]

83. Krueger, A.; Cruickshank, J.; Trevisi, E.; Bionaz, M. Systems for evaluation of welfare on dairy farms. J. Dairy Res. 2020, 87, 13-19. [CrossRef] [PubMed]

84. Stygar, A.H.; Gómez, Y.; Bertesell, G.V.; Costa, E.D.; Canall, E.; Niemi, J.K.; Llonch, P.; Pastell, M. A systematic review on commercially available and validated sensor technologies for welfare assessment for dairy cattle. Front. Vet. Sci. 2021, 8, 634338. [CrossRef]

85. Maltz, E.; Antler, I.; Halachmi, I.; Schmilovitch, Z. Precision concentrate rationing to dairy cow using on-line daily milk composition sensor, milk yield and body weight. In Precision Livestock Farming '09; Wageningen Academic Publishers: Wageningen, The Netherlands, 2009; pp. 17-23.

86. Kwong, K.H.; Wu, T.T.; Sasloglou, K.; Stephen, B.; Cao, D.; Goh, D.; Goh, H.G.; Goo, S.K.; Gilroy, M.; Tachtatzis, C.; et al Implementation of Herd Management System with Wireless Sensor Networks. In Precision Livestock Farming '09; Wageningen Academic Publishers: Wageningen, The Netherlands, 2009; pp. 149-157.

87. Peter, A.T.; Bosu, W.T.K. Postpartum ovarian activity in dairy-cows-Correlation between behavioural oestrus, pedometer measurement and ovulations. Theriogenology 1986, 26, 111-115. [CrossRef]

88. Koelsch, R.K.; Aneshansley, D.J.; Buttler, W.R. Analysis of activity measurement for accurate estrus detection in dairy-cattle. J. Agric. Eng. Res. 1994, 58, 107-114. [CrossRef]

89. Roelofs, J.B.; Van Eerdenburg, E.J.; Soede, N.M.; Kemp, B. Pedometer readings for oestrus detection and as a predictor for time of ovulation in dairy cattle. Theriogenology 2005, 64, 1690-1703. [CrossRef] [PubMed]

90. Kamphuis, C.; Dela Rue, B.; Mein, G.; Jago, J. Development of protocols to evaluate in-line mastitis-detection systems. J. Dairy Sci. 2013, 96, 4047-4058. [CrossRef]

91. Stevenson, J.S.; Smith, M.W.; Jaeger, J.R.; Corah, L.R.; Lefever, D.G. Detection of estrus by visual observation and radiotelemetry in peripubertal, estrus-synchronized beef heifers. J. Anim. Sci. 1996, 74, 729-735. [CrossRef]

92. Lopez, H.; Caraviello, D.Z.; Satter, L.D.; Fricke, P.M.; Wiltbank, M.C. Relationship between level of milk production and multiple ovulations in lactating cows. J. Dairy Sci. 2005, 88, 2783-2793. [CrossRef]

93. Kamphuis, C.; DelaRue, B.; Burke, C.R.; Jago, J. Field evaluation of 2 collar-mounted activity meters for detecting cows in estrus on a large pasture-grazed dairy farm. J. Dairy Sci. 2012, 95, 3045-3056. [CrossRef] [PubMed]

94. Michaelis, I.; Burfeind, O.; Heuwieser, W. Evaluation of oestrus detection in dairy cattle comparing an automated activity monitoring system to visual observation. Reprod. Domest. Anim. 2014, 49,621-628. [CrossRef] [PubMed]

95. Stevenson, J.S.; Hill, S.; Nebel, R.; De Jarnette, J. Ovulation timing and conception risk after automated activity monitoring in lactating dairy cows. J. Dairy Sci. 2014, 97, 4296-4308. [CrossRef]

96. Haladjian, J.; Haug, J.; Nüske, S.; Bruegge, B. A wearable sensor system for lameness detection in dairy cattle. Multimodal Technol. Interact. 2018, 2, 27. [CrossRef]

97. Hempstalk, K.; Burke, C.R.; Kamphuis, C. Verification of an automated camera-based system of oestrus detection in dairy cows. Proc. N. Z. Soc. Anim. Prod. 2013, 73, 26-28.

98. Mayo, L.M.; Silvia, W.J.; Ray, D.L.; Jones, B.W.; Stone, A.E.; Tsai, I.C.; Clark, J.D.; Bewley, J.M.; Heersche, G., Jr. Automated estrous detection using multiple commercial precision dairy monitoring technologies in synchronized dairy cows. J. Dairy Sci. 2019, 102, 2645-2656. [CrossRef]

99. Marquez, H.J.P.; Ambrose, D.J.; Schaefer, A.L.; Cook, N.J.; Bench, C.J. Infrared thermography and behavioral biometrics associated with estrus indicators and ovulation in estrus-synchronized dairy cows housed in tiestalls. J. Dairy Sci. 2019, 102, 4427-4440. [CrossRef]

100. Marquez, H.J.P.; Ambrose, D.J.; Schaefer, A.L.; Cook, N.J.; Bench, C.J. Evaluation of infrared thermography combined with behavioral biometrics for estrus detection in naturally cycling dairy cows. Animal 2021, 15, 100205. [CrossRef] 
101. Yu, G.-M.; Maeda, T. Inline progesterone monitoring in the dairy industry. Trends Biotechnol. 2017, 35, 579-582. [CrossRef]

102. Samsonova, J.V.; Safronova, V.A.; Osipov, A.P. Pretreatment-free lateral flow enzyme immunoassay for progesterone detection in whole cows' milk. Talanta 2015, 132, 685-689. [CrossRef]

103. Gaillard, C.; Barbu, H.; Sørensen, M.T.; Sehested, J.; Callesen, H.; Vestergaard, M. Milk yield and estrous behavior during eight consecutive estruses in Holstein cows fed standardized or high energy diets and grouped according to live weight changes in early lactation. J. Dairy Sci. 2016, 99, 3134-3143. [CrossRef]

104. Pastel, M.E.; Kujala, M. A probabilistic Neural Network Model for lameness detection. J. Dairy Sci. 2007, 90, 2283-2292. [CrossRef] [PubMed]

105. Byabazaire, J.; Olariu, C.; Taneja, M.; Davy, A. Lameness detection as a service: Application of machine learning to an internet of cattle. In Proceedings of the 16th IEEE Annual Consumer Communications and Networking Conference, Las Vegas, NV, USA, 11-14 January 2019. [CrossRef]

106. Taneja, M.; Byabazaire, J.; Jalodia, N.; Davy, A.; Olariu, C.; Malone, P. Machine learning based fog computing assisted data-driven approach for early lameness detection in dairy cattle. Comput. Electron. Agric. 2020, 171, 105286. [CrossRef]

107. Van Hertem, T.; Maltz, E.; Antler, A.; Romanini, C.E.B.; Viazzi, S.; Bahr, C.; Schlageter-Tello, A.; Lokhorst, C.; Berckmans, D.; Halachmi, I. Lameness detection based on multivariate continuous sensing of milk yield, rumination, and neck activity. J. Dairy Sci. 2013, 96, 4286-4298. [CrossRef] [PubMed]

108. Kokin, E.; Praks, J.; Veermäe, I.; Poikalainen, V.; Vallas, M. IceTag 3DTM accelerometric device in cattle lameness detection. Agron. Res. 2014, 12, 223-230.

109. Thorup, V.M.; Nielsen, B.L.; Robert, P.-E.; Giger-Reverdin, S.; Konka, J.; Michie, C.; Friggens, N.C. Lameness affects cow feeding but not rumination behavior as characterized from sensor data. Front. Vet. Sci. 2016, 10, 37. [CrossRef]

110. Poursaberi, A.; Bahr, C.; Pluk, A.; Van Neuffel, A.; Berckmans, D. Real-time automatic lameness detection based on back posture extraction in dairy cattle: Shape analysis of cow with image processing techniques. Comput. Electron. Agric. 2010, 74, 110-119. [CrossRef]

111. Viazzi, S.; Bahr, C.; Schlageter-Tello, A.; Van Hertem, T.; Romanini, C.E.B.; Pluk, A.; Halachmi, I.; Lokhorst, C.; Berckmans, D. Analysis of individual classification of lameness using automatic measurement of back posture in dairy cattle. J. Dairy Sci. 2013, 96, 257-266. [CrossRef]

112. Romanini, C.E.B.; Bahr, C.; Viazzi, S.; Van Hertem, T.; Schlageter-Tello, A.; Halachmi, I.; Lokhorst, K.; Berckmans, D. Application of image based filtering to improve the performance of an automated lameness detection system for dairy cows. In Proceedings of the Annual International Meeting of ASABE, Kansas City, MO, USA, 21-23 July 2013. [CrossRef]

113. Jabbar, K.A.; Hansen, M.F.; Smith, M.L.; Smith, L.N. Early and non-intrusive lameness detection in dairy cows using 3-dimentional video. Biosyst. Eng. 2017, 153, 63-69. [CrossRef]

114. Zhao, K.; Bewley, J.M.; He, D.; Jin, X. Automatic lameness detection in dairy cattle based on leg swing analysis with image processing technique. Comput. Electron. Agric. 2018, 148, 226-236. [CrossRef]

115. Kang, X.; Zhang, X.D.; Liu, G. Accurate detection of lameness in dairy cattle with computer vision: A new and individualized detection strategy based on the analysis of the supporting phase. J. Dairy Sci. 2020, 103, 10628-10638. [CrossRef]

116. Wu, D.; Wu, Q.; Yin, X.; Jiang, B.; Wang, H.; He, D.; Song, H. Lameness detection of dairy cows based on the YOLOv3 deep learning algorithm and a relative step size characteristic vector. Biosyst. Eng. 2020, 189, 150-163. [CrossRef]

117. Cavero, D.; Tolle, K.H.; Buxade, C.; Krieter, J. Mastitis detection in dairy cows by application of fuzzy logic. Livest. Sci. 2006, 105, 207-213. [CrossRef]

118. Khatun, M.; Clark, C.E.F.; Lyons, N.A.; Thomson, P.C.; Kerrisk, K.L.; García, S.C. Early detection of clinical mastitis from electrical conductivity data in automatic milking system. Anim. Prod. Sci. 2017, 57, 1226-1232. [CrossRef]

119. Song, X.; van der Tol, P.P.J. Automatic detection of clinical mastitis in Astronaut A3 TM milking robot. In Proceedings of the 1st North American Conference on Precision Dairy Management, Toronto, ON, Canada, 2-5 March 2010; Available online: http:/ / www.precisiondairy.com/proceedings/s8vandertol.pdf (accessed on 28 May 2020).

120. Friggens, N.C.; Chagunda, M.G.G.; Bjerring, M.; Ridder, C.; Hojsgaard, S.; Larsen, T. Estimating degree of mastitis from time series measurements in milk: A test model based on lactate dehydrogenase measurements. J. Dairy Sci. 2007, 90, 5415-5427. [CrossRef]

121. Jensen, D.B.; Hogeveen, H.; De Vries, A. Bayesian integration of sensor information and a multivariate dynamic linear model for prediction of dairy cow mastitis. J. Dairy Sci. 2016, 99, 7344-7361. [CrossRef]

122. Højsgaard, S.; Friggens, N.C. Quantifying degree if mastitis from common trends in panel of indicators for mastitis in dairy cows. J. Dairy Sci. 2010, 93, 582-592. [CrossRef]

123. Marino, R.; Petrera, F.; Speroni, M.; Rutigliano, T.; Gali, A.; Abeni, F. Unraveling the relationship between milk yield and quality at the test day with rumination time recorded by a PLF technology. Animals 2021, 11, 1583. [CrossRef]

124. Zaninelli, M.; Redaelli, V.; Luzi, F.; Bronzo, V.; Mitchell, M.; Dell'Orto, V.; Bontempo, V.; Cattaneo, D.; Savoini, G. First evaluation of infrared thermography as a tool for the monitoring of udder health status in farms of dairy cows. Sensors 2018, 18, 862. [CrossRef]

125. Zhang, X.; Kang, X.; Feng, N.; Liu, G. Automatic recognition of dairy cow mastitis from thermal images by deep learning detector. Comput. Electron. Agric. 2020, 178, 105754. [CrossRef]

126. Jegadeesan, S.; Venkatesan, G.K.D.P. Distant biometry in cattle farm using wireless sensor networks. In Proceedings of the International Conference on Communication and Electronics Systems (ICCES), Coimbatore, India, 21-22 October 2017. [CrossRef] 
127. Neethirajan, S.; Kemp, B. Digital Livestock Farming. Sens. Biosens. Res. 2021, 32, 100408. [CrossRef]

128. Park, M.-C.; Jung, H.-C.; Kim, T.-K.; Ha, O.-K. Design of cattle health monitoring system using wireless bio-sensor networks. In Electronics, Communications and Networks IV, 1st ed.; Hussain, A., Ivanovic, M., Eds.; CRC Press: Boca Raton, FL, USA, 2015; pp. 225-228.

129. Reith, S.; Hoy, S. Relationship between daily rumination time and estrus of dairy cows. J. Dairy Sci. 2012, 95, 6416-6420. [CrossRef] [PubMed]

130. Schirmann, K.; von Keyserlingk, M.A.; Weary, D.M.; Veira, D.M.; Heuwieser, W. Validation of a system for monitoring rumination in dairy cows. J. Dairy Sci. 2009, 92, 6052-6055. [CrossRef] [PubMed]

131. Steinmetz, M.; von Soosten, D.; Hummel, J.; Meyer, U.; Dänicke, S. Validation of the RumiWatch Converter V0. 7.4 .5 classification accuracy for the automatic monitoring of behavioural characteristics in dairy cows. Arch. Anim. Nutr. 2020, 74, 164-172. [CrossRef] [PubMed]

132. Zehner, N.; Umstätter, C.; Niederhauser, J.J.; Schick, M. System specification and validation of a noseband pressure sensor for measurement of ruminating and eating behavior in stable-fed cows. Comput. Electron. Agric. 2017, 136, 31-41. [CrossRef]

133. Andrew, W.; Greatwood, C.; Burghardt, T. Fusing animal biometrics with autonomous robotics: Drone-based search and individual ID of Friesian cattle. In Proceedings of the IEEE/CVF Winter Conference on Applications of Computer Vision (WACV) Workshops, Snowmass, CO, USA, 1-5 March 2020. [CrossRef]

134. Kumar, S.; Singh, S.K. Cattle recognition: A new frontier in visual animal biometrics research. Proc. Natl. Acad. Sci. India Sect. A Phys. Sci. 2019, 90, 689-708. [CrossRef]

135. Okura, F.; Ikuma, S.; Makihara, Y.; Muramatsu, D.; Nakada, K.; Yagi, Y. RGB-D video-based individual identification of dairy cows using gait and texture analyses. Comput. Electron. Agric. 2019, 165, 104944. [CrossRef]

136. Martins, B.M.; Mendes, A.L.C.; Silva, L.F.; Moreira, T.R.; Costa, J.H.C.; Rotta, P.P.; Chizzotti, M.L.; Marcondes, M.I. Estimating body weight, body condition score, and type traits in dairy cows using three dimensional cameras and manual body measurements Livest. Sci. 2020, 236, 104054. [CrossRef]

137. Pezzuolo, A.; Guarino, M.; Sartori, L.; Marinello, F. A feasibility on the use of a structured light depth-camera for three-dimensional body measurements of dairy cows in free-stall barns. Sensors 2018, 18, 673. [CrossRef]

138. Halachmi, I.; Polak, P.; Roberts, D.J.; Klopčič, M. Cow body shape and automation of condition scoring. J. Dairy Sci. 2008, 91, 4444-4451. [CrossRef]

139. Halachmi, I.; Klopčič, M.; Polak, P.; Roberts, D.J.; Bewley, J.M. Automatic assessment of dairy cattle body condition score using thermal imaging. Comput. Electron. Agric. 2013, 99, 35-40. [CrossRef]

140. Bewley, J.M.; Peacock, A.M.; Lewis, O.; Boyce, R.E.; Roberts, D.J.; Coffey, M.P.; Kenyon, S.J.; Schutz, M.M. Potential for estimation of body condition scores in dairy cattle from digital images. J. Dairy Sci. 2008, 91, 3439-3453. [CrossRef] [PubMed]

141. Cha, E.; Hertl, J.A.; Bar, D.; Gröhn, Y.T. The cost of different types of lameness in dairy cows calculated by dynamic programming Prev. Vet. Med. 2010, 97, 1-8. [CrossRef]

142. Hernandez, J.; Shearer, J.K.; Webb, D.W. Effect of lameness on milk yield in dairy cows. J. Am. Vet. Med. Assoc. 2002, 220, 640-644. [CrossRef] [PubMed]

143. Onyiro, O.M.; Offer, J.; Brotherstone, S. Risk farctors and milk yield losses associated with lameness in Holstein-Friesian dairy cattle. Animal 2008, 2, 1230-1237. [CrossRef]

144. Morris, M.J.; Kaneko, K.; Walker, S.L.; Jones, D.N.; Routly, J.E.; Smith, R.F.; Dobson, H. Influence of lameness on follicular growth, ovulation, reproductive hormone concentrations and estrus behavior in dairy cows. Theriogenology 2011, 76, 658-668. [CrossRef] [PubMed]

145. Peake, K.A.; Biggs, A.M.; Smith, R.F.; Christley, R.M.; Routly, J.E.; Dobson, H. Effects of lameness, subclinical mastitis and loss of body condition on the reproductive performance of dairy cows. Vet. Rec. 2011, 168, 301. [CrossRef] [PubMed]

146. Booth, C.J.; Warnick, L.D.; Grohn, Y.T.; Maizon, D.O.; Guard, C.L.; Jansen, D. Effect of lameness on culling in dairy cows. J. Dairy Sci. 2004, 87, 4115-4122. [CrossRef]

147. Thomsen, P.T.; Munksgaard, L.; Tøgersen, F.A. Evaluation of a lameness system for dairy cows. J. Dairy Sci. 2008, 91, 119-126. [CrossRef] [PubMed]

148. Mc Manus, C.; Tanure, C.B.; Peripolli, V.; Seixas, L.; Fischer, V.; Gabbi, A.M.; Menegassi, S.R.O.; Stumpf, M.T.; Kolling, G.J.; Dias, E.; et al. Infrared thermography in animal production: An overview. Comput. Electron. Agric. 2016, 123, 10-16. [CrossRef]

149. Ruegg, P.L. A 100-Year Review: Mastitis detection, management, and prevention. J. Dairy Sci. 2017, 100, 10381-10397. [CrossRef]

150. Breed, R.S.; Brew, J.D. The control of public milk supplies by the use of the microscopic method. J. Dairy Sci. 1917, 1, 259-271. [CrossRef]

151. Kitchen, B.J. Review of the progress of dairy science: Bovine mastitis: Milk composition changes and related diagnostic tests. J. Dairy Res. 1981, 48, 167-188. [CrossRef] [PubMed]

152. Kemp, M.; Nolan, A.; Cripps, P.; Fitzpatrick, J. Animal-based measurements on the severity of mastitis in dairy cows. Vet. Rec. 2008, 163, 175-179. [CrossRef] [PubMed]

153. Huijps, K.; Lam, T.J.; Hogeveen, H. Costs of mastitis: Facts and perception. J. Dairy Res. 2008, 75, 113-120. [CrossRef]

154. Rosa, G.J.M. Grand challenge in Precision Livestock Farming. Front. Anim. Sci. 2021, 2, 650324. [CrossRef]

155. Rutten, D.J.; Velthuis, G.J.; Steeneveld, W.; Hogeveen, H. Invited review: Sensors to support health management of dairy farms. J. Dairy Sci. 2013, 96, 1928-1952. [CrossRef] [PubMed]

156. Morgan-Davies, C.; Lambe, N.; Wishart, H.; Waterhouse, T.; Kenyon, F.; McBean, D.; McCracken, D. Impacts of using a precision livestock system targeted approach in mountain flocks. Livest. Sci. 2018, 208, 67-76. [CrossRef] 
157. Wishart, H.M. Precision Livestock Farming: Potential Application for Sheep Systems in Harsh Environments. Ph.D. Thesis, University of Edinburgh, Edinburgh, UK, 2019.

158. Mansbridge, N.; Mitsch, J.; Bollard, N.; Ellis, K.; Miguel-Pacheco, G.G.; Dottorini, T.; Kaler, J. Feature selection and comparison of machine learning algorithms in classification of grazing and rumination behaviour in sheep. Sensors 2018, 18, 3532. [CrossRef] [PubMed]

159. Barwick, J.; Lamb, D.W.; Dobos, R.; Welch, M.; Trotter, M. Categorising sheep activity using a tri-axial accelerometer. Comput. Electron. Agric. 2018, 145, 289-297. [CrossRef]

160. Virgilio, A.D.; Morales, J.M.; Lambertucci, S.A.; Shepard, E.L.C.; Wilson, R.P. Multi-dimensional Precision Livestock Farming: A potential toolbox for sustainable rangeland management. PeerJ 2018, 6, e4867. [CrossRef]

161. Meunier, B.; Giname, C.; Houdebine, M.; Fleurance, G.; Mialon, M.-M.; Siberberg, M.; Boisy, A. Development of a multi-sensor and multi-application device for monitoring indoor and outdoor sheep behaviour. In Proceedings of the 7th European Conference of Precision Livestock Farming (EC-PLF), Milan, Italy, 15 September 2015; p. 12.

162. Beker, A.; Gipson, T.A.; Puchala, R.; Askar, A.R.; Tesfai, K.; Detweiler, G.D.; Asmare, A.; Goetsch, A.L. Energy expenditure and activity of different types of small ruminants grazing varying pastures in the summer. J. Appl. Anim. Res. 2010, 37, 1-14. [CrossRef]

163. Betteridge, K.; Hoogendoorn, C.; Costall, D.; Carter, M.; Griffiths, W. Sensors for detecting and logging spatial distribution of urine patches of grazing female sheep and cattle. Comput. Electron. Agric. 2010, 73, 66-73. [CrossRef]

164. Burgunder, J.; Petrželková, K.; Modrý, D.; Kato, A.; Maclntosh, A.J.J. Fractal measurements in activity patterns: Do gastrointestinal parasites affect the complexity of sheep behaviour? Appl. Anim. Behav. Sci. 2018, 205, 44-53. [CrossRef]

165. Mozo, R.; Alabart, J.L.; Rivas, E.; Folch, J. New method to automatically evaluate the sexual activity of the ram based on accelerometer records. Small Rumin. Res. 2019, 172, 16-22. [CrossRef]

166. Cronin, G.M.; Beganovic, D.F.; Sutton, A.L.; Palmer, D.J.; Thomson, P.C.; Tammen, I. Manifestation of neuronal ceroid lipofuscinosis in Australian Merino sheep: Observations on altered behaviour and growth. Appl. Anim. Behav. Sci. 2016, 175, 32-40. [CrossRef] [PubMed]

167. Alvarenga, F.A.P.; Borges, I.; Palkovič, L.; Rodina, J.; Oddy, V.H.; Dobos, R.C. Using a three-axis accelerometer to identify and classify sheep behaviour at pasture. Appl. Anim. Behav. Sci. 2016, 181, 91-99. [CrossRef]

168. Yiakoulaki, M.D.; Hasanagas, N.D.; Michelaki, E.; Tsiobani, E.T.; Antoniou, I. Social network analysis of sheep grazing different plant functional groups. Grass Forage Sci. 2018, 74, 129-140. [CrossRef]

169. Alhamada, M.; Debus, N.; Lurette, A.; Bocquier, F. Validation of automated electronic oestrus detection in sheep as an alternative to visual observation. Small Rumin. Res. 2016, 134, 97-104. [CrossRef]

170. Alhamada, M.; Debus, N.; Lurette, A.; Bocquier, F. Automatic oestrus detection system enables monitoring of sexual behaviour in sheep. Small Rumin. Res. 2017, 149, 105-111. [CrossRef]

171. de Freitas, A.C.B.; Vega, W.H.O.; Quirino, C.R.; Bartholazzi, A., Jr.; David, C.M.G.; Geraldo, A.T.; Rua, M.A.S.; Rojas, L.F.C.; de Filho, J.E.A.; Dias, A.J.B. Surface temperature of ewes during estrous cycle measured by infrared thermography. Theriogenology 2018, 119, 245-259. [CrossRef] [PubMed]

172. Façanha, D.A.E.; Peixoto, G.C.X.; Ferreira, J.B.; de Sousa, J.E.R.; Paiva, R.D.M.; Ricarte, A.R.F. Detecting estrus in Canindé goats by two infrared thermography methods. Acta Vet. Bras. 2018, 12, 49-54. [CrossRef]

173. Byrne, D.T.; Berry, D.P.; Esmonde, H.; McGovern, F.; Creighton, P.H.; McHugh, N. Infrared thermography as a tool to detect hoof lesions in sheep. Transl. Anim. Sci. 2019, 3, 577-588. [CrossRef]

174. Byrne, D.T.; Esmonde, H.; Berry, D.P.; McGovern, F.; Creighton, P.; McHugh, N. Sheep lameness detection from individual hoof load. Comput. Electron. Agric. 2019, 158, 241-248. [CrossRef]

175. Abecia, J.A.; Maria, G.A.; Estévez-Moreno, L.X.; Miranda-De La Lama, G.C. Daily rhythms of body temperature around lambing in sheep measured non-invasively. Biol. Rhythm Res. 2019, 51, 988-993. [CrossRef]

176. Fuchs, B.; Sørheim, K.M.; Chincarini, M.; Brunberg, E.; Stubsjøen, S.M.; Bratbergsengen, K.; Hvasshovd, S.O.; Zimmermann, B.; Lande, U.S.; Grøva, L. Heart rate sensor validation and seasonal and diurinal variation of body temperature and heart rate in domestic sheep. Vet. Anim. Sci. 2019, 8, 100075. [CrossRef] [PubMed]

177. Ribó, O.; Korn, C.; Meloni, U.; Cropper, M.; De Winne, P.; Cuypers, M. IDEA: A large-scale project on electronic identification of livestock. Rev. Sci. Tech. 2001, 20, 426-436. [CrossRef]

178. Bortolotti, L.; Zampieri, A.; Miatto, A. Practical experience on the use of injectable transponders in flock of Quessant sheep. Large Anim. Rev. 2013, 19, 219-223.

179. Voulodimos, A.S.; Patrikakis, C.Z.; Sideridis, A.B.; Ntafis, V.A.; Xylouri, E.M. 2010. A complete farm management system based on animal identification using RFID technology. Comput. Electron. Agric. 2010, 70, 380-388. [CrossRef]

180. Cappai, M.G.; Rubiu, N.G.; Nieddu, G.; Bitti, M.P.L.; Pinna, W. Analysis of fieldwork activities during milk production recording in dairy ewes by means of individual ear tag (ET) alone or plus RFID based electronic identification (EID). Comput. Electron. Agric. 2018, 144, 324-328. [CrossRef]

181. Hentz, F.; Umstätter, C.; Gilaverte, S.; Prado, O.R.; Silva, S.J.A.; Monteiro, A.L.G. Electronic bolus design impacts on administration. J. Anim. Sci. 2014, 92, 2686-2692. [CrossRef]

182. Xu, B.; Wang, W.; Falzon, G.; Kwan, P.; Guo, L.; Sun, Z.; Li, C. Livestock classification and counting in quadcopter aerial images using Mask R-CNN. Int. J. Remote Sens. 2020, 41, 8121-8142. [CrossRef] 
183. Bishop, J.C.; Falzon, G.; Trotter, M.; Kwan, P.; Meek, P.D. Sound analysis and detection, and the potential for precision livestock farming-A sheep vocalization case study. In Proceedings of the 1st Asian-Australasian Conference on Precision Pastures and Livestock Farming, Hamilton, Australia, 16-18 October 2017. [CrossRef]

184. Al-Thani, N.; Albuainain, A.; Alnaimi, F.; Zorba, N. Drones for sheep livestock monitoring. In Proceedings of the 20th Mediterranean Electrotechnical Conference (MELECON), Palermo, Italy, 16-18 June 2020. [CrossRef]

185. Ren, K.; Karlsson, J.; Liuska, M.; Hartikainen, M.; Hansen, I.; Jørgensen, G.H.M. A sensor-fusion-system for tracking sheep location and behaviour. Int. J. Distrib. Sens. Netw. 2020, 16, 155014772092177. [CrossRef]

186. Zobel, G.; Weary, D.M.; Leslie, K.; Chapinal, N.; von Keyserlingk, M.A.G. Technical note: Validation of data logger for recording behavior in dairy goats. J. Dairy Sci. 2015, 98, 1082-1089. [CrossRef]

187. Jouven, M.; Leroy, H.; Ickowicz, A.; Lapeyronie, P. Can virtual fences be used to control grazing sheep? Rangelands 2011, 34, 111-123. [CrossRef]

188. Brunberg, E.I.; Bøe, K.E.; Sørheim, K.M. Testing a new virtual system on sheep. Acta Agric. Scand. A Anim. Sci. 2015, 65, 168-175. [CrossRef]

189. Brunberg, E.I.; Bergslid, I.K.; Bøe, K.E.; Sørheim, K.M. The ability of ewes with lambs to learn a virtual fencing system. Animal 2017, 11, 2045-2050. [CrossRef]

190. Marini, D.; Llewellyn, R.; Belson, S.; Lee, C. Controlling within-field sheep movement using virtual fencing. Animals 2018, 8, 31. [CrossRef] [PubMed]

191. Marini, D.; Meuleman, M.D.; Belson, S.; Rodenburg, T.B.; Llewellyn, R.; Lee, C. Developing an ethically virtual fencing system for sheep. Animals 2018, 8, 33. [CrossRef]

192. Kearton, T.; Marini, D.; Cowley, F.; Belson, S.; Lee, C. The effect of virtual fencing stimuli on stress responses and behaviour in sheep. Animals 2019, 9, 30. [CrossRef] [PubMed]

193. Fay, P.K.; McElligot, V.T.; Havstad, K.M. Containment of free-ranging goats using pulsed-radio-wave-activates shock collars. Appl. Anim. Behav. Sci. 1989, 23, 165-171. [CrossRef]

194. Alejandro, M. Automation devices in sheep and goat machine milking. Small Rumin. Res. 2016, 142, 48-50. [CrossRef]

195. Bueso-Ródenas, J.; Romero, G.; Arias, R.; Rodrígez, A.M.; Díaz, J.R. Effect of automatic cluster removers on milking efficiency and teat condition of Machenga ewes. J. Dairy Sci. 2015, 98, 3887-3895. [CrossRef] [PubMed]

196. Romero, G.; Bueso-Ródenas, J.; Gascó, P.; Díaz, J.R. Effect of the automatic cluster removers (ACRs) in the milking of MurcianoGranadina goats during lactation. Small Rumin. Res. 2015, 128, 54-58. [CrossRef]

197. Ramsahoi, L.; Gao, A.; Fabri, M.; Odumeru, J.A. Assessment of the application of an automated electronic milk analyzer for the enumeration of total bacteria in raw goat milk. J. Dairy Sci. 2001, 94, 3279-3287. [CrossRef]

198. Sevi, A.; Taibi, L.; Albenzio, M.; Muscio, A.; Dell'Aquila, S.; Napolitano, F. Behavioral, adrenal, immune, and reproductive responses of lactating ewes to regrouping and relocation. J. Anim. Sci. 2001, 79, 1457-1465. [CrossRef]

199. Papachristoforou, C.; Tzamaloukas, O. Innovations have improved the efficiency of ruminant production systems in Cyprus. In New Trends for Innovation in the Mediterranean Animal Production, 1st ed.; Bouche, R., Derkimba, A., Casabianca, F., Eds.; Wageningen Academic Publishers: Wageningen, The Netherlands, 2009; pp. 217-226. [CrossRef] 